\title{
A FORMAÇÃO SUPERIOR NOS ROMANCES MEMÓRIAS PÓSTUMAS DE BRÁS CUBAS, DE MACHADO DE ASSIS, E OS IRMÃOS KARAMÁZOVI, DE FIÓDOR DOSTOIÉVSKI
}

\author{
Luís Henrique de Freitas Calabresi \\ Universidade Federal de São Carlos - UFSCar \\ henriq_fc@yahoo.com.br \\ Marisa Bittar \\ Universidade Federal de São Carlos - UFSCar \\ bittar@ufscar.br
}

\section{RESUMO}

Este artigo tem por objetivo analisar elementos em comum na formação superior da elite no Brasil e na Rússia no século XIX por meio do estudo dos romances Memórias Póstumas de Brás Cubas, de Machado de Assis, e Os Irmãos Karamázovi, de Fiódor Dostoiévski. Excertos destas obras com alusões ao nosso tema de estudo foram analisados em relação a outras fontes históricas. Foram encontradas similaridades, tais como a ênfase no ensino superior, por meio de um modelo que destacava a erudição intelectual com fins de ostentação, em detrimento do desenvolvimento da vida prática e das forças produtivas, criando uma ilha de letrados, detentores de uma cultura humanística e de uma retórica extremamente sofisticada e vazia, abandonando as massas populares à ignorância. Esta formação superior contribuiu para a opressão de classe e para o aprofundamento das desigualdades sociais.

Palavras-chave: Brasil; Rússia; educação superior; literatura

\section{HIGHER EDUCATION IN THE NOVELS THE POSTHUMOUS MEMOIRS OF BRAS CUBAS, BY MACHADO DE ASSIS, AND THE BROTHERS KARAMAZOV, BY FYODOR DOSTOEVSKY}

\begin{abstract}
This article aims at analyzing elements in common in the elite's higher education in Brazil and Russia in the nineteenth century through the study of the novels The Posthumous Memoirs of Bras Cubas, by Machado de Assis, and The Brothers Karamazov, by Fyodor Dostoevsky. Excerpts from these works related to our theme were analyzed with regard to other historical sources. Similarities were found, such as the emphasis on higher education through a model which highlighted intellectual erudition, aiming at ostentation, to the detriment of the development of practical life and productive forces, and creating an island of literates, holders of a humanistic culture and an extremely sophisticated and empty rhetoric, abandoning the popular masses to ignorance. This higher education system contributed to class oppression and the deepening of social inequalities.
\end{abstract}

Keywords: Brazil; Russia; higher education; literature 


\section{Introdução}

O estudo de obras literárias pode trazer muitas contribuições à compreensão de elementos históricos, filosóficos e sociológicos de uma determinada sociedade, em um tempo determinado. Em um trecho de uma correspondência de Friedrich Engels, ao analisar características do romance realista Comédie Humaine de Balzac, o autor afirma:

E em torno desta imagem central, o autor tece uma história completa da sociedade francesa, com a qual, mesmo em pormenores econômicos (como, por exemplo, a distribuição da propriedade real e privada após a Revolução Francesa), aprendi mais do que com todos os historiadores, economistas e estatísticos profissionais do período. (ENGELS; MARX, 1986, p. 71)

Seguindo essa linha de pensamento, autores como Astrojildo Pereira, Raymundo Faoro, Roberto Schwarz, John Gledson e Sidney Chalhoub, discutindo a obra de Machado de Assis, e Elisabete Xavier, analisando a obra de vários autores literários, demonstraram as grandes potencialidades do estudo da literatura para a compreensão do Brasil, em seus diversos aspectos, de modo amplamente convincente ${ }^{1}$. Em concordância com esta premissa teórica, foi realizada a pesquisa que deu origem à dissertação de mestrado em Educação, pela Universidade Federal de São Carlos, relacionando Literatura e História da Educação, intitulada A formação superior em Direito na obra de Machado de Assis. (CALABRESI, 2008) Na ocasião, foi investigada a formação superior em Direito, por meio do estudo de dois romances de Machado de Assis, Memórias Póstumas de Brás Cubas e Dom Casmurro, realizando-se o entrecruzamento do texto literário com outras fontes pertinentes da historiografia durante o século XIX. Entre as características mais fortes e presentes na formação dos intelectuais brasileiros contemporâneos de Machado de Assis, em sua maioria bacharéis em Direito, estava a cultura humanística, desvinculada da realidade produtiva do país e atrelada a uma retórica extremamente sofisticada e vazia, utilizada com fins de ostentação e ilustração intelectual de seus detentores e de opressão de classe.

$\mathrm{Na}$ presente pesquisa, fomos surpreendidos com uma passagem do romance $O s$ Irmãos Karamázovi, ${ }^{2}$ do autor russo Fiódor Dostoiévski, publicado em 1880, na qual Alieksiéi Karamázov, o mais novo dos irmãos que dão nome a esta obra, está conversando com um jovem estudante russo, chamado Kólia:

- Ah! Sorri por uma razão bem diversa. Fique sabendo: li uma recente opinião de um estrangeiro, um alemão que vivia na Rússia, a respeito da juventude estudantil de hoje: "se mostrardes a um estudante russo", escreveu ele, "uma carta do firmamento, a respeito da qual não tinha ele até então nenhuma idéia, ele vo-la devolverá no dia seguinte com correções." Conhecimentos nulos e uma presunção sem limites, eis o que queria dizer o alemão a respeito do estudante russo. (DOSTOIÉVSKI, 2008, p. 930)

A menção da opinião deste personagem literário alemão nos lembrava diretamente as espirituosas observações de Ina von Binzer, preceptora alemã que viveu no Brasil entre os anos de 1882 e 1884, sobre os estudantes brasileiros:

Os brasileiros dão ótimos advogados, podendo dessa maneira aproveitar seu talento declamatório. Dão a vida por falar, mesmo quando é para não dizer nada. Com a eloquiência que esbanjam num único discurso, poder-se-iam compor 
facilmente dez em nossa terra; embora não possuam verdadeira eloqüência nem marcada personalidade, falando todos com a mesma cadência tradicional usada em toda e qualquer circunstância. Tudo é exterior, tudo é gesticulação e meia cultura. $\mathrm{O}$ fraseado pomposo, a eloqüência enfática já são por si só falsos e teatrais; mas se você tirar a prova real, se indagar sobre qualquer assunto, não se revelam capazes de fornecer a informação desejada. [...] Alguns dão opinião sobre línguas estrangeiras, mas não sabem explicar nenhuma regra da sua própria. [...] Não se encontra profundidade em parte alguma... (BINZER, 1994, p. 95)

Podemos observar, nestes dois excertos, que no mesmo período histórico, uma educadora alemã no Brasil e um personagem de ficção alemão, criado por Dostoiévski, emitem opiniões muito semelhantes sobre os estudantes russos e brasileiros, respectivamente. Ambos fazem referência à presunção intelectual e a conhecimentos vazios, desprovidos de sustentação interna, elementos que Machado de Assis expôs de modo magistral no romance Memórias Póstumas de Brás Cubas, publicado em 1881, por meio da voz do personagem que dá título à obra, ao comentar seus estudos de filosofia:

Não digo que a Universidade não me tivesse ensinado alguma; mas eu decorei-lhe só as fórmulas, o vocabulário, o esqueleto. Tratei-a como tratei o latim; embolsei três versos de Virgílio, dous de Horácio, uma dúzia de locuções morais e políticas, para as despesas da conversação. Tratei-os como tratei a história da jurisprudência. Colhi de todas as cousas a fraseologia, a casca, a ornamentação... (ASSIS, 1959, p. 446)

Dentro do tema do ensino superior, podemos destacar que o romance Memórias Póstumas de Brás Cubas, por meio de seu defunto autor, e o romance Os Irmãos Karamázovi, por meio do personagem Ivan Karamázov, apresentam personagens oriundos da elite aristocrática, que freqüentaram cursos superiores. Brás Cubas cursou Direito na Universidade de Coimbra, em Portugal, e Ivan Karamázov cursou Ciências Naturais na Universidade de Moscou, na Rússia. ${ }^{3}$

Considerando as questões expostas anteriormente, este artigo tem por objetivo investigar a existência de possíveis elementos em comum na formação superior da elite do Brasil e da Rússia no século XIX, por meio do estudo dos romances Memórias Póstumas de Brás Cubas, de Machado de Assis, e Os Irmãos Karamázovi, de Fiódor Dostoiévski. Para alcançar tal objetivo, iniciaremos nosso estudo com um levantamento de questões históricas que nos auxiliarão na compreensão da lógica social de nossas fontes literárias, para em seguida passarmos à discussão dos excertos dos romances em suas referências aos elementos educacionais relativos à formação superior da elite.

\section{O panorama histórico do Brasil e da Rússia no século XIX}

O Brasil do século XIX, no qual Machado de Assis escreveu as Memórias Póstumas de Brás Cubas, apresentava uma sociedade marcada pelos grandes latifúndios, a escravidão e a produção de gêneros primários para a exportação. A população brasileira dividia-se em latifundiários, escravos e uma classe intermediária, os homens livres, ou "dependentes". Segundo Faoro (1985), a grande propriedade servia como afirmação do poder da camada aristocrática, que predominava em todo o país. De acordo com Costa (1999), estas oligarquias, apesar de terem optado pelo regime monárquico em 1822, 
exerciam forte pressão sobre o governo central para concentrar o poder em suas mãos. Estes grupos de elite eram formados por fazendeiros e comerciantes, que compunham os quadros governantes e administrativos do Estado recém-criado, tais como cadeiras no Conselho de Estado, no Senado, na Câmara dos Deputados, nas presidências das províncias e nos ministérios de Estado, e buscavam títulos de nobreza. Uma grande parte dos membros desta oligarquia realizou seus estudos em Portugal, notadamente na Universidade de Coimbra, uma instituição de ensino de grande prestígio à época.

De acordo com o pesquisador brasilianista Robert Conrad, (1972) apesar de o governo brasileiro da época ostentar com grandiosidade sua organização em uma monarquia parlamentar, um imperador sofisticado e uma legislatura bicameral, no interior das províncias o poder se concentrava nas mãos dos proprietários rurais.

Portanto, estes grupos de elite estavam empenhados na manutenção das mesmas relações econômicas de produção, baseadas nos latifúndios, na ampla utilização de mãode-obra escrava, na exclusão das camadas populares do poder por meio do mecanismo do voto censitário e pela não extensão da cidadania aos índios e escravos, que constituíam uma porcentagem considerável da população. Para se ter uma idéia desta porcentagem, de acordo com Costa (1999), por exemplo, no recenseamento da capitania de Minas Gerais, Vila Rica, em 1804, havia um total de 8.180 pessoas recenseadas, das quais, 6.087 livres e 2.893 escravos, sendo a maioria da população composta de crioulos e pardos. Ainda segundo a autora, as linhas de classe e de cor coincidiam tanto na zona urbana quanto na zona rural, e nos lugares em que havia brancos e homens de cor, os primeiros representavam sempre a elite. De modo geral, as condições inibidoras do desenvolvimento urbano no período colonial mantiveram-se no século XIX. Nesse contexto, a Igreja era o único lugar público onde todas as classes se reuniam. Artesanato, comércio, letras, artes, burocracia e política constituíam veículos de ascensão social. Esse mecanismo, que se processou de acordo com um sistema de clientela, permitiu a pouquíssimos negros e mulatos, em geral filhos ilegítimos de algum branco economicamente bem situado, ascenderem na escala social. Foi o caso do próprio Machado de Assis.

Os grupos da elite, deste modo, ao concentrarem o poder, mantinham ao redor de si uma enorme rede de dependentes, livres ou cativos, que buscavam a proteção de latifundiários em troca de favores, formando redes de clientela, citadas anteriomente, paternalismo e patronagem, que tiveram origem no período colonial e intensificaram a hegemonia das oligarquias sobre o restante da população.

Neste contexto, as elites procuraram construir a figura paternalista do senhor generoso, ao qual os membros das outras classes sociais deveriam sempre demonstrar gratidão. Segundo a visão senhorial, como demonstrou Chalhoub, (2003) todas as movimentações dos dependentes eram vistas como expansões da vontade do proprietário, num mundo aparentemente harmônico de relações verticais. Porém, esta figura supostamente generosa e bondosa escondia a brutalidade da autoridade senhorial, ou seja, a "inviolabilidade da vontade senhorial"[...]"que organiza e dá sentido às relações sociais que a circundam". (Ibid., 2003, p. 20) Lembramos, a propósito, que a já citada preceptora alemã surpreendeu-se ao constatar, nas fazendas em que trabalhou, o hábito de os escravos batizarem seus filhos com os nomes dos seus patrões.

Entre os valores aristocráticos predominantes, de acordo com Costa, estavam a "desvalorização do trabalho manual, fenômeno típico de sociedades escravistas; culto ao lazer; espírito rotineiro; pouco apreço pelo processo tecnológico e científico; relações de dependência; família extensiva; tendência à ostentação." (1999, p. 239). Podemos observar que estes valores, juntamente com o sistema de clientela e patronagem, não contribuíram para o desenvolvimento de núcleos e valores burgueses europeus. O sistema escravista, 
deste modo, degradava o trabalho, especialmente o manual. Do ponto de vista dos brancos, aristocratas ou dependentes, o trabalho era ocupação dos negros, ou seja, de escravos, estando impregnado por uma aura aviltante. Por outro lado, na visão dos cativos, ao trabalho estavam incorporadas práticas de tortura e maus tratos, associando-se desta forma a idéia de liberdade à ausência do trabalho. Conforme destaca Costa, podemos observar que a escravidão não se restringiu a influenciar o trabalho de maneira marcante, como também as relações entre os homens:

Dessa forma, a escravidão ultrajava a idéia de trabalho, e, o que é ainda mais grave, degradava as relações entre os homens. Num regime escravista, o respeito mútuo necessário à verdadeira coesão social não existe. A lei consagra as distinções sociais, legitima-as e, quando procura garantir a classe oprimida, torna-se letra morta, ineficaz, burlada pelos interesses dominantes. (Ibid., 1999, p. 15-16)

Reportando-nos agora à Rússia, constatamos que a sociedade imperial do século XIX, na qual o romance Os Irmãos Karamázovi foi escrito, era predominantemente rural, tal como a brasileira do mesmo período. No alto desta sociedade se situava o czar, com plenos poderes autocráticos, que considerava as terras, as pessoas e todos os recursos constituintes do Império Russo como sua propriedade particular. (BUCHER, 2008)

As relações produtivas eram marcadas pelo regime de servidão, que vigorou até 1861, no qual os servos, que representavam a maioria da população, eram legalmente presos à terra em que viviam e a seus senhores, que poderiam vendê-los juntamente com suas terras. Esse processo nos lembra o sistema feudal, em que os servos eram adstritos aos senhores feudais. Os proprietários de terras e de servos formavam a nobreza russa, um grupo aristocrático que vivia de práticas econômicas agrárias retrógradas e do exercício de cargos públicos da autocracia estatal, orbitando ao redor do czar, com uma prática secular de busca de interesses particulares e vantagens pessoais. Os cargos desta burocracia estatal, na maioria das vezes, não eram ocupados seguindo critérios de competência técnica ou méritos, mas sim por critérios de nascimento, influências e proximidade em relação ao czar, caracterizando uma enraizada rede de relações de favor. Também eram muito freqüentes as práticas de corrupção nas administrações provinciais e na coleta de impostos. (BLUM, 1961; BLACK; SETON-WATSON, 1969 )

No início do século XIX, reflexos das transformações ocorridas na Europa ocidental em séculos anteriores, como a Revolução Francesa, a Revolução Industrial e o Iluminismo, começaram a causar conflitos que abalaram a autocracia russa, que, na grande maioria dos casos, adotou medidas repressoras austeras para a manutenção da ordem. Nas décadas de 1840 e 1850, ganhou força entre os intelectuais russos um caloroso debate entre a tendência ocidentalizadora, que defendia o progresso por meio da assimilação do racionalismo e das liberdades cívicas, e a tendência eslavófila, que afirmava a superioridade espiritual da Rússia em relação ao oeste, além de preconizar que o desenvolvimento da Rússia deveria basear-se nas tradições da Igreja Ortodoxa russa e na organização econômica servil. A propósito, o próprio Dostoiévski viveu conflitos de ordem existencial devido a essa polarização de valores, tomando partido da corrente eslavófila. (LEATHERBARROW, 1993)

Em 1861, no calor dos debates, aconteceu a emancipação dos servos. Por meio da militância nos inúmeros jornais fundados nessa época, foi possível observar que o setor ocidentalista passou por mudanças de posicionamento em relação a seus predecessores das décadas de 1840 e 1850. Ao invés do liberalismo humanista, os movimentos dos anos de 1860 radicalizaram sua oposição ao czarismo, propondo a rejeição de todas as tradições e a 
reconstrução da sociedade russa a partir de fundamentos puramente científicos e racionais, partindo para ações armadas, tendo como alvos membros da burocracia estatal. (BUCHER, 2008)

Devido a processos de ordem e causalidade diversas, Brasil e Rússia se encontravam numa posição periférica em relação aos países centrais do capitalismo, localizados na Europa ocidental. Schwarz, partindo das relações entre história e literatura, estabelece pontos em comum entre Machado de Assis e autores da literatura russa. Para ele:

O sistema de ambigüidades assim ligadas ao uso local do ideário burguês - uma das chaves do romance russo - pode ser comparado àquele que descrevemos para o Brasil. São evidentes as razões desta semelhança. Também na Rússia a modernização se perdia na imensidão do território e na inércia social, entrava em choque com a instituição servil e com seus restos -, choque experimentado como inferioridade e vergonha nacional por muitos, sem prejuízo de dar a outros um critério para medir o desvario do progressismo e do individualismo que o Ocidente impunha e impõe ao mundo. Na exacerbação deste confronto, em que o progresso é uma desgraça e o atraso uma vergonha, está uma das raízes profundas da literatura russa. Sem forçar em demasia uma comparação desigual, há em Machado - pelas razões que sumariamente procurei apontar - um veio semelhante, algo de Gogol, Dostoiévski, Gontcharov, Tchecov, e de outros talvez, que não conheço. (SCHWARZ, 2000, p. 28)

Ouros historiadores, como Aarão (2003), fazem referência a certos aspectos históricos que, guardadas as suas devidas especificidades, podem ser encontrados em ambos países, tais como a ocorrência de uma sociedade agrária e atrasada, que dispunha de técnicas ultrapassadas que conduziam a uma baixa produtividade, os valores elitistas de ociosidade e preguiça, juntamente com um processo de lento declínio, ao final do século XIX, dos grupos aristocráticos e início da ascensão de grupos burgueses.

Em relação à educação também é possível encontrar elementos semelhantes, como por exemplo o acesso elitizado ao ensino, a predominância do analfabetismo entre a maioria da população, a predominância do ensino superior, seguido em importância pelo ensino secundário, com menosprezo pelo ensino primário, e a forte presença da Igreja Católica no Brasil e da Igreja Ortodoxa na Rússia em assuntos educacionais. (LUEDEMANN, 2002)

Ainda acerca da predominância do ensino superior, podemos observar em Romanelli (1978) que, durante o século XIX, este nível de ensino obteve monopólio sobre os níveis primário, que contava com pouquíssimas escolas, e secundário, que tinha um caráter meramente propedêutico, e, por esse motivo, tinha seus conteúdos condicionados e estruturados pelo ensino superior. Sobre a educação russa do mesmo período, McClelland (1979), nos indica a predominância do ensino superior, seguido pelo ensino secundário, apontando para o fato de que o ensino primário, a despeito do aumento das verbas a este destinadas no final do século XIX, ainda ficava muito aquém dos outros dois níveis de ensino.

Após o levantamento de questões relativas ao contexto histórico destes dois países, passaremos para a análise das obras literárias, com o objetivo de elucidar as contribuições que elas podem trazer para a melhor compreensão da formação superior da elite em suas respectivas sociedades e seu tempo. 


\section{A formação superior no romance Memórias Póstumas de Brás Cubas}

O romance Memórias Póstumas de Brás Cubas, de Machado de Assis, foi escrito em primeira pessoa. O narrador, Brás Cubas, na condição de defunto, relata sua vida. Brás é um representante da classe senhorial, sendo proprietário de terras e de escravos, e o enredo do romance discorre sobre as futilidades e caprichos deste aristocrata, que tinha todas as suas vontades obedecidas prontamente desde sua infância, tendo até mesmo um escravo para que ele montasse, como se este fosse um cavalo. Após gastar grandes somas de dinheiro com prostitutas, ele é enviado para estudar na Europa, o que faz com notória displicência. Ao retornar ao Brasil, se envolve em um caso extraconjugal com Virgília, mulher casada com o político Lobo Neves, se aventura, de maneira banal, pela política, pelo jornalismo, pela filosofia, entre outros projetos, que nunca são concluídos de modo consistente. Segundo Schwarz (1990), a propriedade escravista e clientelista brasileira, que o dispensa de trabalhar, se configura como o elemento que permite a Brás Cubas esta vida de leviandade.

O personagem do narrador está inserido na política de dominação paternalista, na qual impera a inviolabilidade da vontade senhorial, que traz consigo uma visão de mundo na qual toda a movimentação dos dependentes é considerada expansão da vontade do senhor. (CHALHOUB, 2003) Outro aspecto que consideramos sobremaneira importante para nossa investigação se refere ao fato de o narrador ser um bacharel em Direito.

Desse modo, destacamos que:

Em Memórias Póstumas de Brás Cubas, o "defunto autor", narrador vivíssimo aliás, aproveita-se de sua condição para contar episódios de sua vida com independência e sinceridade, pois a "franqueza é a primeira virtude de um defunto". Desafrontado do mundo, desdenhoso das opiniões alheias - "não há nada tão incomensurável como o desdém dos finados" (BC, cap. XXIV) -, Brás pode agora confessar "lisamente o que foi", "estender" aos outros as revelações que antes só podia fazer à própria consciência. O sentido político dessas características do narrador é potencialmente explosivo: afinal, um legítimo representante da classe senhorial, em vida um herdeiro e continuador de suas prerrogativas, resolve se expor abertamente, dizer a verdade sobre si mesmo e, por conseguinte, sobre aqueles que a ele se assemelham quanto às "tradições de família", "cabedais" e "relações adquiridas". (Ibid., 2003, p.72-73)

Conforme observamos acima, o narrador se coloca numa posição supostamente distante da sociedade em que viveu, rompendo seus laços diretos pela morte, o que, nas palavras do próprio narrador, lhe traz liberdade para expor o que sempre ocultara quando em vida. Deste modo, a narrativa adquire um tom irônico e sarcástico, no qual o narrador zomba dos outros personagens e também dos leitores. Com Brás Cubas liberado das amarras dos escrúpulos e normas sociais repressoras, sua narrativa torna-se uma crítica bastante refinada da sociedade brasileira do século XIX.

Com o intuito de dar maior visibilidade a essa condição assumida pelo personagem, passaremos agora para a análise dos excertos de Memórias Póstumas de Brás Cubas. Primeiros abordaremos aspectos mais gerais, destacando a atuação da classe senhorial e o papel da formação jurídica. O excerto a seguir mostra Brás Cubas exercitando sua "filosofia" acerca da função da ponta do nariz, comentando a afirmação do doutor Pangloss que considera que o nariz serve para segurar os óculos. Num arrebatamento de iluminação, 
Brás atina para a verdadeira função do nariz, lançando mão do exemplo do faquir, para tentar exemplificar seu achado filosófico:

Nariz, consciência sem remorsos, tu me valeste muito na vida... Já meditaste alguma vez no destino do nariz, amado leitor? A explicação do doutor Pangloss é que o nariz foi criado para uso dos óculos, - e tal explicação confesso que até certo tempo me pareceu definitiva; mas veio um dia, em que, estando a ruminar esse e outros pontos obscuros da filosofia, atinei com a única, verdadeira e definitiva explicação.

Com efeito, bastou-me atentar no costume de faquir. Sabe o leitor que o faquir gasta longas horas a olhar para a ponta do nariz, com o fim único de ver a luz celeste. Quando ele finca os olhos na ponta do nariz, perde o sentimento das cousas externas, embeleza-se no invisível, apreende o impalpável, desvincula-se da terra, dissolve-se, eteriza-se. Essa sublimação do ser pela ponta do nariz é o fenômeno mais excelso do espírito, e a faculdade de a obter não pertence ao faquir somente: é universal. Cada homem tem a necessidade e o poder de contemplar o seu próprio nariz, para o fim de ver a luz celeste, e tal contemplação, cujo efeito é a subordinação do universo a um nariz somente, constitui o equilíbrio das sociedades. Se os narizes se contemplassem uns aos outros, o gênero humano não chegaria a durar dous séculos: extinguia-se com as primeiras tribos. (ASSIS, 1959, p. 467)

Chalhoub (2003) propõe que este texto é uma metáfora política, com um toque interpretativo no narrador. Enquanto o faquir, ao se lançar à contemplação do próprio nariz e se desligar das "cousas externas", o faz com o fim de ascensão celestial e ascetismo, Brás contempla seu nariz com fins de afirmação do autoritarismo de sua classe, ao considerar que as "cousas externas" são justamente os outros atores sociais antagônicos que devem ser eliminados, dentro da visão de mundo senhorial.

Por nossa vez, entendemos que a formação em Direito se encaixa de maneira bastante harmoniosa nesta visão de mundo senhorial, considerando que ela teve como uma de suas funções a homogeneização da elite, com vistas a formar letrados com cultura humanística, erudita, alheia à realidade material imediata, com uma retórica refinada, que, segundo Adorno (1988), legislavam e governavam o país minimizando as contradições sociais de classe nos conflitos existentes à época, restringindo-se à contemplação e subordinação do mundo a seus narizes.

A respeito da formação superior e jurídica propriamente dita, selecionamos cinco excertos bastante valiosos e reveladores, todos eles relacionados ao contexto em que Brás é enviado a Portugal para realizar seus estudos superiores na Universidade de Coimbra. No primeiro dos excertos, Brás discorre sobre suas possibilidades de escolha entre várias carreiras universitárias e profissionais e suas expectativas em relação ao futuro:

Um grande futuro! Enquanto esta palavra me batia no ouvido, devolvia eu os olhos, ao longe, no horizonte misterioso e vago. Uma idéia expelia outra, a ambição desmontava Marcela. Grande futuro? Talvez naturalista, literato, arqueólogo, banqueiro, político, ou até bispo, - bispo que fosse, uma vez que fosse um cargo, uma proeminência, uma grande reputação, uma posição superior. A ambição, dado que fosse águia, quebrou nessa ocasião o ovo, e desvendou a pupila fulva e penetrante. Adeus, amores! Adeus Marcela! Dias de delírio, jóias sem preço, vida sem regímen, adeus! Cá me vou às fadigas e à glória; deixo-vos com as calcinhas da primeira idade. (ASSIS, 1959, p. 442) 
Podemos observar que o fator decisivo para a escolha da carreira não se encontrava em características e peculiaridades das carreiras em si mesmas, mas sim nas perspectivas de se alcançar proeminência, glórias e prestígio social, uma distinção em relação aos outros grupos sociais. É possível concluir, então, que Brás, como um representante da classe senhorial, manifestava um alto grau de frivolidade em relação à formação profissional propriamente dita, não sendo possível enxergar algo que pudéssemos denominar como vocação para os estudos.

Chegando a Portugal, ele relata-nos, de maneira debochada, seu cotidiano estudantil, sua relação com os estudos e sua graduação:

E foi assim que desembarquei em Lisboa e segui para Coimbra. A Universidade esperava-me com as suas matérias árduas; estudei-as muito mediocremente, e nem por isso perdi o grau de bacharel; deram-mo com a solenidade do estilo, aos anos da lei; uma bela festa que me encheu de orgulho e saudades - principalmente saudades. Tinha eu conquistado em Coimbra uma grande nomeada de folião; era um acadêmico estróina, superficial, tumultuário e petulante, dado às aventuras, fazendo romantismo prático e liberalismo teórico, vivendo na pura fé dos olhos pretos e das constituições escritas. No dia em que a universidade me atestou, em pergaminho, uma ciência que eu estava longe de trazer arraigada no cérebro, confesso que me achei de algum modo logrado, ainda que orgulhoso. Explico-me: o diploma era uma carta de alforria; se me dava a liberdade, dava me a responsabilidade. Guardei-o, deixei as margens do Mondego, e vim por aqui fora assaz desconsolado, mas sentindo já uns ímpetos, uma curiosidade, um desejo de acotovelar os outros, de influir, de gozar, de viver, - de prolongar a Universidade vida adiante... (Ibid., 1959, p. 442)

Este excerto nos faz muitas revelações, de maneira bastante direta e sarcástica, coerente com as características do narrador discutidas anteriormente. Em relação à passagem citada acima, observamos a atitude de menosprezo, de descaso e a desvalorização com a qual Brás realiza seus estudos. A utilização de termos como "folião" "acadêmico estróina", "superficial", "tumultuário", "petulante" e "dado a aventuras" deixa bem clara a postura acadêmica de Brás, sua falta de compromisso com os estudos. Sua afirmação de que se sentira logrado ao receber o diploma pode ser entendida como um reconhecimento bastante enfático de que sua postura acadêmica foi praticamente inócua em termos de aprendizado. A volta ao Brasil é vista com ressalvas devido a possíveis responsabilidades. O fechamento do excerto é brilhante do ponto de vista de nossa pesquisa, visto que os desejos de "influir", "acotovelar os outros", "gozar" e "viver" nos indicam sua disposição para assumir as prerrogativas autoritárias de sua classe senhorial e, ironicamente, prolongar a universidade no Rio de Janeiro - ou seja, viver de modo tão fútil e frívolo como o fizera em Coimbra.

De volta ao Brasil, Brás faz um balanço de seu aprendizado na universidade, em um excerto cuja parte final foi citada anteriormente na introdução deste artigo:

Para lhes dizer a verdade toda, eu refletia as opiniões de um cabeleireiro, que achei em Módena, e que se distinguia por não as ter absolutamente. Era a flor dos cabeleireiros; por mais demorada que fosse a operação do toucado, não enfadava nunca; ele intercalava as penteadas com muito motes e pulhas, cheias de um pico, de um sabor... Não tinha outra 
filosofia. Nem eu. Não digo que a Universidade não me tivesse ensinado alguma; mas eu decorei-lhe só as fórmulas, o vocabulário, o esqueleto. Tratei-a como tratei o latim; embolsei três versos de Virgílio, dous de Horácio, uma dúzia de locuções morais e políticas, para as despesas da conversação. Tratei-os como tratei a história da jurisprudência. Colhi de todas as cousas a fraseologia, a casca, a ornamentação... (Ibid., 1959, p. 446)

Esta é mais uma exposição do vazio de conhecimentos da formação de Brás Cubas, que explica sem pudores e de maneira reiterada que somente adquiriu aspectos exteriores e superficiais dos campos do conhecimento aos quais se lançou ao estudo, mais úteis para "as despesas da conversação", ou seja, para ostentar uma imagem ilustrada perante os outros grupos sociais e também perante outros membros da elite.

Essa página da literatura novamente nos evoca os espirituosos comentários da preceptora alemã Ina von Binzer, citada no início deste artigo, a respeito do "talento declamatório dos brasileiros". E no caso dessas cartas, a preceptora registrou exatamente o que presenciou nas casas da aristocracia agrária onde trabalhou. É pertinente lembrarmos algumas de suas referências aos intelectuais brasileiros, considerando que estes "Dão a vida por falar, mesmo quando é para não dizer nada", e em seguida "Com a eloqüência que esbanjam num único discurso, poder-se-iam compor facilmente dez em nossa terra". (1994, p. 95) Ela conclui esta observação afirmando que esta dita eloqüência mostrava-se vazia diante de questionamentos sistemáticos, provando ser exterior e teatral.

Voltando a Brás, algum tempo após se estabelecer no Rio de Janeiro, é eleito deputado, confirmando as colocações de Cunha (1980), segundo as quais a carreira política era uma consequiência da aquisição do grau de bacharel em Direito. Aliás, Joaquim Nabuco (1975) já escrevera que a Faculdade de Direito era a ante-sala da Câmara. Porém, Brás passa um certo tempo sem se envolver em grandes debates, quando um dia, instado pelo amigo filósofo, Quincas Borba, que o estimulava para a atuação política de maneira bastante entusiasmada, resolve fazer uma intervenção. Em suas palavras:

[...] discutindo-se o orçamento da justiça, aproveitei o ensejo para perguntar modestamente ao ministro se não julgava útil diminuir a barretina da guarda nacional. Não tinha vasto alcance o objeto da pergunta; mas ainda assim demonstrei que não era indigno das cogitações de um homem de Estado. (ASSIS, 1959, p. 534)

A partir deste momento, Brás inicia um inflamado discurso que tem como tema as inúmeras benéfices da redução do tamanho da barretina utilizada pelos oficiais da guarda nacional. A última sentença do excerto citado acima é de uma ironia mordaz, acerca do caráter de dignidade das "cogitações de um homem de Estado". Em seu discurso, ele cita Filopémen e Hipócrates, e constrói uma série de artifícios retóricos. A reação dos outros membros do Parlamento ao final do discurso é relatada pelo narrador com as seguintes palavras:

Vária foi a impressão deste discurso. Quanto à forma, ao rapto eloqüente, à parte literária e filosófica, a opinião foi uma só: disseram-me todos que era completo, e que de uma barretina ninguém ainda conseguira tirar tantas idéias. (Ibid., 1959, p. 535) 
Se sua eloqüência foi bastante elogiada, por outro lado o conteúdo político de seu discurso foi duramente criticado por seus pares. Ao fracassar em sua tentativa de se tornar um ministro de Estado ele perde suas ilusões em relação à política, que não passou de mais um de seus caprichos.

\section{A formação superior no romance Os Irmãos Karamázovi}

O romance Os Irmãos Karamázovi nos apresenta, em seu enredo, o proprietário de terras Fiódor Karamázov, que adentrou a aristocracia agrária russa por vias pouco honrosas e é caracterizado por uma conduta dissoluta, repugnante e avarenta. De seu primeiro casamento nasceu seu filho primogênito, Dimítri Fiódorovitch Karamázov, seguido pelo nascimento, de seu segundo casamento, de Ivan Fiódorovitch Karamázov e de Alieksiéi Fiódorovitch Karamázov. A estes três irmãos, que dão título ao romance, é acrescentado um filho bastardo de Fiódor, chamado Smierdiákov, que assassina seu pai. Entretanto, várias evidências inculpam Dimítri, o filho mais velho, que é condenado injustamente, por meio de um julgamento, que pode ser considerado um dos grandes episódios desta obra

Ao discutir este romance é importante considerar a análise que Mikhail Bakhtin (2008) faz deste grande autor, especialmente em relação ao conceito de romance polifônico, por meio do qual numa mesma obra há diversas vozes que expressam visões filosóficas contraditórias e excludentes, defendidas por diferentes personagens. Segundo este conceito, estas diferentes vozes ocupam o primeiro plano da narrativa e obscurecem as concepções do próprio autor.

Segundo Richard Pevear, (1992) na construção da narrativa d'Os Irmãos Karamázovi, estão presentes extensos diálogos e monólogos, que atribuem à obra características de linguagem oral, mais do que da linguagem escrita. Destes diálogos e monólogos emergem uma enorme variedade de personagens, extremamente contraditórios entre si e, segundo críticos, relativamente independentes de seu autor. Dentre estas inúmeras vozes, a primeira que nos é apresentada é a do narrador, que não é a voz de Dostoiévski. O próprio narrador se apresenta, no início do romance, como supérfluo, e faz uso recorrente de proposições evasivas e expressões repetitivas, e, de acordo com Pevear, este se caracteriza como um escritor amador, mais um falante do que um escritor. Este narrador evasivo não imprime uma única voz autoral a este romance. Em alguns momentos ele cede espaço a um narrador mais onisciente e convencional, e grande parte das cenas é narrada pelo ângulo pessoal do personagem que está sendo descrito, ocorrendo mudanças acentuadas de linguagem entre os personagens principais.

Passaremos, neste momento, para a análise dos excertos deste romance relacionados à formação superior da elite. Dos três irmãos do título do romance, Dimítri, Ivan e Alieksiéi Karamázov, este último também chamado pelo seu diminutivo, Aliócha, apenas Ivan, o filho do meio, atingiu o grau mais alto de escolaridade, tendo concluído seus estudos superiores. O irmão mais velho, Dimítri Karamázov, "deixou o ginásio antes do termo, entrou em seguida para uma escola militar, partiu para o Cáucaso, serviu no exército [...]". (DOSTOIÉVSKI, 2008, p. 500)

Alieksiéi Karamázov, o irmão mais novo, também não concluiu os estudos secundários, deixando a escola secundária de uma pequena cidade provincial um ano antes de sua conclusão, para posteriormente ingressar em um mosteiro. Sobre seus anos escolares, podemos ler que "Na classe, era um dos melhores alunos, mas nunca obteve o primeiro lugar." (Ibid., 2008, p. 507)

Um desempenho bastante diferente foi demonstrado por Ivan Karamázov: 
Esse rapaz mostrou, desde sua mais tenra idade (pelo que se conta, pelo menos), brilhantes capacidades para o estudo. Com a idade de cerca de treze anos deixou a família de Iefim Pietróvitch [Iefim Pietróvitch ficou responsável pela criação de Ivan e Alieksiéi após os irmãos deixarem a casa do pai, Fiódor Karamázov] para seguir os cursos de um ginásio de Moscou, e tomar pensão em casa de um famoso pedagogo, amigo de infância de seu benfeitor. Mais tarde, Ivan contava que Iefim Pietróvitch fora inspirado por seu "ardor pelo bem" e pela idéias de que um adolescente genial devia ser educado por um educador genial." (Ibid., 2008, p. 503)

Terminado o ginásio, Ivan prossegue seus estudos na Universidade de Moscou, ao cursar Ciências Naturais. Este curso superior se inseria no sistema educacional russo, que se originara no século XVII, com o czar Pedro o Grande, tendo sido importado da Europa ocidental, enfrentando uma série de resistências por parte da nobreza. A autocracia russa precisava de profissionais qualificados para ocupar os quadros do serviço governamental, e que fossem obedientes ao Estado. Entre as unidades educacionais que compunham esse sistema, destacavam-se os ginásios, as academias militares e a universidades. Os ginásios, de caráter propedêutico, situados em Moscou, - onde Ivan Karamazov estudou - ou em outras grandes cidades, como Khazan, conferiam mais prestígio e vantagens para o acesso às universidades. As escolas secundárias de pequenas cidades provinciais, onde Alieksiéi estudara, eram muito mais modestas. As academias militares, que Dimítri Karamázov frequentara, distinguiam-se por difundirem um conteúdo científico muito diluído, além de serem pouco exigentes nos estudos, funcionando como uma espécie de concessão à nobreza, que poderia alcançar altos postos no serviço governamental sem passar pelo rigor de estudos das universidades. Estas por sua vez, formavam uma rede, que teve início com a Universidade de Moscou, freqüentada por Ivan Karamázov, e granjearam um alto padrão acadêmico. Esse sistema educacional, de marcada influência ocidental, era extremamente elitista e abandonava a grande maioria da população à obscuridade intelectual. (ALSTON, 1969; MCCLELLAND, 1979).

Em outras passagens do texto, encontramos excertos que reforçam as distinções educacionais entre os irmãos, como por exemplo neste cotejamento entre Dimítri e Ivan: "comparado a seu irmão, Dimítri era quase um ignorante; o contraste da personalidade deles e de seus caracteres era tão vivo que se teria dificilmente imaginado dois seres tão diferentes." (DOSTOIÉVSKI, 2008, p. 516) E também por meio dos pensamentos do religioso Alieksiéi, ao tentar entender a indiferença de Ivan: “[...] perguntou igualmente a si mesmo se não havia naquilo o desprezo de um ateu sábio por um pobre noviço." (Ibid., 2008, p. 516)

Ivan Karamázov, brilhante intelectual, gozava de aprovação e aclamações vindas de diversos personagens, como por exemplo de Madame Kokhlakov, uma personagem caracterizada pela futilidade: "[...] um jovem tão sábio, de aparência tão altiva e tão reservada [...] esse excelente rapaz tão instruído". (Ibid., 2008, p. 504) Um pouco adiante: "Dizia a mim mesma: ele é tão culto, um universitário [...]" (Ibid., 2008, p. 653), e ainda: "o querido Ivan Fiódorovitch, tão instruído e que possuía tão belas maneiras." (Ibid., 2008, p. 801) O diabo, que lhe aparece em um delírio, também profere palavras elogiosas sobre Ivan: "Meu amigo, conheço um encantador jovem russo, amador de literatura e de arte." (Ibid., 2008, p. 1003) E o promotor, durante o julgamento de Dimítri Karamázov, ao fim do romance, afirma: "[...] é um destes rapazes modernos, brilhantes pela sua instrução e pela sua inteligência, que não crê em nada [...] (Ibid., 2008, p. 1039) 
O personagem Miúsov, tio dos irmãos protagonistas, que é apresentado pelo narrador como um ocidental, livre pensador e ateu, que residiu por muitos anos na França, e teria participado da Comuna de Paris, nos indica suas impressões acerca do sobrinho intelectual:

Estava surpreendido mais que todos, tendo travado conhecimento com o rapaz que o interessava bastante e com o qual rivalizava em erudição. "Ele é altivo, dizia-nos. - Saberá sempre arranjar-se; desde agora, tem com que partir para o estrangeiro. Que faz ele aqui?" (Ibid., 2008, p. 505)

Todos estes copiosos elogios confirmam o prestígio de uma formação cultural sofisticada e elitista, que atribuía proeminência a seus detentores por meio dos conhecimentos científicos e artísticos, juntamente com um verniz de "boas maneiras" européias. Neste ponto é preciso fazer menção às disputas intelectuais do século XIX na Rússia entre as tendências ocidentalistas e eslavófilas, referidas previamente neste artigo. O grupo ocidentalista tinha origem, em grande parte, dentro das universidades, composto por estudantes e professores, que formavam a chamada intelligentsia acadêmica, e articulavam tendências oriundas principalmente da Alemanha, Inglaterra e França, como o liberalismo, o socialismo e o niilismo. (MCLELLAND, 1979) Neste clima de agitação ideológica, o posicionamento ateísta era muito presente dentro dos setores da intelligentsia, manifestando-se nos personagens Ivan Karamázov e Miúsov. Possivelmente, o ateísmo professado por tais personagens tivesse por objetivo confrontar o czarismo e seus vínculos com a Igreja Ortodoxa Russa.

No momento em que a narrativa se desenrola, Ivan já concluíra seus estudos superiores e está prestes a partir para a Europa ocidental, para dar continuidade ao seu desenvolvimento intelectual. Podemos observar suas elevadas expectativas em relação ao encontro com a tradição cultural européia por meio de suas próprias palavras dirigidas ao irmão Aliócha:

- Quero viajar pela Europa, Aliócha. Sei que não encontrarei lá senão um cemitério, mas quão querido! Queridos mortos nele repousam, cada pedra atesta a vida ardente deles, sua fé apaixonada nos seus ideais, sua luta pela verdade e pela ciência. Oh! Cairei de joelhos diante daquelas pedras, beijá-las-ei, derramando lágrimas. Convencido, aliás, intimamente, de que tudo aquilo não é senão um cemitério e nada mais. (DOSTOIÉVSKI, 2008, p. 682)

Durante os anos de universidade, devido a complicações financeiras temporárias, Ivan é forçado a trabalhar para ganhar seu sustento, publicando uma série de artigos na imprensa, que receberam uma acolhida favorável nos círculos intelectuais russos. Seu último artigo foi publicado em um grande jornal, e versou sobre a questão dos tribunais eclesiásticos, tema bastante polêmico à época, que dividia setores religiosos e "profanos". No entanto, algumas questões despertaram certo estranhamento, como podemos observar no excerto a seguir, que trata do último artigo de Ivan e de sua repercussão:

O assunto era-lhe aparentemente desconhecido, uma vez que seguira os cursos de Ciências Naturais e o artigo tratava a questão dos tribunais eclesiásticos, suscitada, então, por toda parte. Examinando algumas opiniões emitidas a respeito dessa matéria, expunha igualmente suas opiniões pessoais. O que impressionava, era o tom e o inesperado da 
conclusão. Ora, muitos eclesiásticos tinham o autor como seu partidário. Por outra parte, os leigos, bem como os ateus, aplaudiam suas idéias. Afinal de contas, algumas pessoas decidiram que o artigo não passava de uma desavergonhada mistificação. (Ibid., 2008, p. 504)

Ivan, possivelmente, não tinha familiaridade com o assunto dos tribunais eclesiásticos, visto que era formado em outra área, Ciências Naturais, e ao escrever um artigo sobre uma questão polêmica da época que agradou a ambas as posições antagonistas, levantou suspeitas de ser uma "desavergonhada mistificação"

No mosteiro da pequena cidade onde se passa o romance, aconteceu uma discussão sobre este artigo, que reuniu religiosos, incluindo uma grande autoridade da Igreja Ortodoxa, chamada stáriets e os três irmãos Karamázovi. Um dos padres diz sobre o artigo:

- Comentamos um artigo bastante curioso do senhor - explicou o padre Iósif, o bibliotecário, designando Ivan Fiódorovitch. - Há muitas apreciações novas, mas a tese parece de dois gumes. É um artigo em resposta a um padre, autor de uma obra a respeito dos tribunais eclesiásticos. (Ibid., 2008, p. 541)

Um pouco adiante, podemos ver um diálogo entre o stáriets e o autor do artigo, Ivan, sobre o artigo em questão, juntamente a uma teoria de Ivan Karamázov, relativa à imortalidade da alma. Segundo esta teoria, a existência da imortalidade da alma e de Deus são importantes para a manutenção da coesão e a ordem social, pois, segundo seu elaborador, se Deus não existisse, tudo seria permitido, o que levaria inevitavelmente ao estabelecimento do caos social:

- É feliz se assim acredita; pode-se ser muito infeliz!

- Por que infeliz? - objetou Ivan Fiódorovitch, sorrindo.

- Porque, segundo toda aparência, não crê o senhor nem na imortalidade da alma, nem mesmo no que escreveu a respeito da questão da Igreja.

- Talvez o senhor tenha razão!... No entanto, não brinquei absolutamente - confessou de modo estranho Ivan Fiódorovitch, corando imediatamente.

- O senhor não brincou absolutamente, é verdade. [...] No momento, é por desespero que o senhor se diverte com artigos de revistas e com discussões mundanas, sem acreditar na sua dialética e zombando dela dolorosamente a sós consigo. (Ibid., 2008, p. 549)

É importante realçar também a visão de outro personagem, o seminarista ambicioso Rakítin, sobre o artigo de Ivan e sua teoria acerca da imortalidade da alma, em conversa com Alieksiéi: "Teu irmão Ivan distrai-se agora escrevendo artigos de teologia por um cálculo estúpido que se ignora, sendo ele próprio ateu, e confessa essa baixeza." (Ibid., 2008, p. 558)

Mais adiante, o mesmo Rakítin, sobre Ivan e os estudantes universitários: "Os fanfarrões da escola com uma 'profundeza de pensamento insolúvel'. É um falastraz e isto quer dizer simplesmente no fundo: 'Boné branco e branco boné.' Toda a sua teoria não passa de uma infâmia!” (Ibid., 2008, p. 559)

Para compreender a lógica social da discussão sobre o artigo e a teoria de Ivan, e situá-la em relação ao panorama educacional da época, é necessário entender o modelo de formação escolar da juventude russa, especialmente dos cursos de formação superior. As universidades, desde sua gênese em solo russo, receberam altos investimentos e atenções 
prioritárias. Estas instituições de ensino, que se estruturaram a partir de modelos europeus ocidentais, tinham centros de pesquisa de elevado padrão. Entretanto, a pesquisa e o ensino praticados nas universidades russas eram balizados pelo princípio da nauka, termo russo que quer dizer conhecimento puro. A nauka estava associada a um alto desenvolvimento de conhecimentos teóricos e abstratos, juntamente com um florescimento das artes e dos clássicos, dissociados das necessidades práticas urgentes do país. McClelland (1979) afirma que este modelo de sistema universitário, que possibilitou um desenvolvimento de uma cultura nacional extremamente requintada, também serviu para perpetuar e intensificar as disparidades entre as classes sociais. O currículo vigente nas universidades, centrado no conhecimento puro, negligenciou modelos de qualificação destinados a atender as necessidades práticas e produtivas da Rússia, o que poderia contribuir para a superação de seus enormes problemas sociais e econômicos da época. Ao mesmo tempo, este contribuía para manter o quadro estrutural daquela sociedade, como o regime de servidão, por exemplo. Concluímos assim que este ensino superior elitista e academicista produziu uma intelligentsia alienada, o que por sua vez contribuiu para a ampliação da distância entre os poucos letrados e as massas de analfabetos.

Por meio dos excertos da obra Os Irmãos Karamázovi que fazem referência ao artigo e à teoria da imortalidade da alma e da existência de Deus de Ivan Karamázov, citados anteriormente, observamos várias características deste sistema universitário. Ivan se diverte em disputas intelectuais, nas quais intervém com sua dialética e sua erudição refinada, articulando jogos de idéias abstratas, que podem ser consideradas dúbias, ambíguas, isentas de coerências em relação às suas próprias crenças, podendo ainda simplesmente não significar nada, ou seja: serviriam apenas para uso retórico. A fúria contra este pensamento academicista vem do seminarista inescrupuloso, Rakítin, que acusa Ivan, juntamente com os intelectuais russos de "fanfarrões", que pretendem discutir assuntos altamente elevados e profundos, mas que não passam de insignificâncias e "infâmias".

Entretanto, o próprio Ivan nos revela um ponto de vista bastante diferente a respeito destas mesmas discussões intelectuais, em uma conversa com seu irmão Alieksiéi. Nos excertos a seguir, primeiramente, ele fala sobre o que chama de "questões eternas":

Nós outros, fedelhos, temos como tarefa resolver as questões eternas, eis nosso fim. Agora, toda a jovem Rússia só faz dissertar sobre essas questões primordiais, ao passo que os velhos se limitam às questões práticas. [...]

Questões eternas - a situação fatal da Rússia? O estrangeiro? O Imperador Napoleão? (DOSTOIÉVSKI, 2008, p. 684)

Mais adiante, durante a mesma conversa, Ivan nos fornece outros detalhes sobre como ocorriam as discussões entre a juventude russa, a respeito do que ele chama agora de "questões universais":

Como procede a juventude russa, pelo menos uma parte? Vai para um botequim de ar viciado, tal como este, por exemplo, e instala-se num canto. Esses rapazes não se conhecem e ficarão quarenta anos sem tornar a encontrar-se. Que discutem eles naqueles breves minutos? Apenas questões essenciais: se Deus existe, se a alma é imortal. Os que não crêem em Deus discorrem sobre o socialismo, a anarquia, sobre a renovação da humanidade; ora, essas questões são as mesmas, mas 
encaradas sob outra face. E boa parte da juventude russa, a mais original, hipnotiza-se com essas questões. Não é verdade? (Ibid., 2008, p. 685)

Observamos nas palavras de Ivan uma posição oposta à defendida por Rakítin acerca das discussões intelectuais dos estudantes. O intelectual, membro da intelligentsia, por manter íntimas ligações com o sistema de ensino superior russo, faz claramente a defesa da nauka, ou seja, do conhecimento puro. Este personagem também apresenta um considerável distanciamento de questões práticas de seu país.

\section{Conclusão}

Apesar de aspectos específicos relativos à formação histórica dos dois países aqui tratados, podemos observar nas obras analisadas alguns elementos em comum no tocante à formação superior da elite no Brasil e na Rússia durante o século XIX. Ambos países priorizaram o ensino superior, por meio de um modelo que destacava a erudição intelectual, com fins de ostentação, em detrimento do desenvolvimento da vida prática e das forças produtivas, que criava, segundo José Murilo de Carvalho, uma ilha de letrados (1996), detentores de uma cultura humanística e retórica exuberante, e abandonava as massas populares à ignorância. Este modelo de ensino universitário contribuiu para a promoção da opressão de classe (SCHWARZ, 1997) e para o aprofundamento das desigualdades sociais (MCLELLAND, 1979)

Para concluir nosso estudo, consideramos importante acrescentar que, além dos elementos relativos ao ensino superior mencionados acima, tanto no Brasil como na Rússia o acesso ao ensino de modo geral era marcadamente elitista, com uma escola primária para poucos, um ensino secundário propedêutico e a predominância de uma população analfabeta.

\section{Referências:}

FILHO, Daniel. As revoluções russas e o socialismo soviético. Coleção Revoluções do Século 20, direção: Emilia Viotti da Costa. São Paulo: Editora UNESP, 2003.

ADORNO, Sérgio. Os aprendizes do poder: o bacharelismo liberal na política brasileira. Rio de Janeiro: Paz e Terra, 1988.

ALSTON, Patrick L. Education and the State in Tsarist Russia. Stanford: Stanford University Press, 1969.

ASSIS, Machado de. Machado de Assis: obra completa. COUTINHO, Afrânio (org). Rio de Janeiro: Nova Aguilar, 1959, vol. I.

BAKHTIN, Mikhail. Problemas da poética de Dostoiévski. Rio de Janeiro: Forense Universitária, 2008.

BINZER, Ina von. Os meus romanos: alegrias e tristezas de uma educadora alemã no Brasil. $6^{a}$ ed. Tradução Alice Rossi e Luisita da Gama Cerqueira. Rio de Janeiro: Paz e Terra, 1994. 
BLACK, Cyril; SETON-WATSON, Hugh. The nature of Imperial Russian society. In: RIHA, Thomas (Editor). Readings in Russian civilization. Volume II, Imperial Russia, 1700-1917. Chicago, London: The University of Chicago Press, 1969.

BLUM, Jerome. Lord and Peasant in Russia: from the ninth to the nineteenth century. Princeton: Princeton University Press, 1961.

BUCHER, Greta. Daily life in Imperial Russia. Westport, London: Greenwood Press, 2008.

CALABRESI, Luís Henrique de Freitas. A formação superior em Direito na obra de Machado de Assis. Dissertação de Mestrado. Programa de Pós-Graduação em Educação UFSCar, São Carlos, 2008.

CARVALHO, José Murilo de. A construção da ordem: a elite política imperial; Teatro de sombras: a política imperial. $2^{a}$ ed. rev. Rio de Janeiro: Ed. UFRJ, Relume-Dumará, 1996.

CHALHOUB, Sidney. Machado de Assis: historiador. São Paulo: Companhia das Letras, 2003.

CONRAD, Robert. The destruction of Brazilian slavery: 1850 - 1888. Berkeley; Los Angeles: University of California Press, 1972.

COSTA, Emilia Viotti da. Da monarquia à república: momentos decisivos. $7^{\mathrm{a}}$ ed. São Paulo: Ed. UNESP, 1999.

CUNHA, Luiz Antonio. A universidade temporã: da Colônia à era Vargas. Rio de Janeiro: Civilização Brasileira: 1980.

DOSTOIÉVSKI, Fiódor M. Obra Completa. Natália Nunes e Oscar Mendes (trad.). Rio de Janeiro: Nova Aguilar, 2008.

ENGELS, Friedrich, MARX, Karl. Sobre literatura e arte. Global Editora: São Paulo, 1986.

FAORO, Raymundo. Machado de Assis: a pirâmide e o trapézio. $3^{\text {a }}$ ed. Rio de Janeiro: Globo, 1988.

FAORO, Raymundo. Os donos do poder: a formação do patronato político brasileiro. $6^{\mathrm{a}}$ ed. Porto Alegre: Globo, 1985. v.2.

GLEDSON, John. Machado de Assis - impostura e realismo: uma reinterpretação de Dom Casmurro. Tradução Fernando Py. São Paulo: Companhia das Letras, 1991.

LEATHERBARROW, W. J. Introduction. In: DOSTOEVSKY, Fyodor. Crime and Punishment. London: Everyman's Library, 1993.

LUEDEMANN, Cecília da Silveira. Anton Makarenko: a pedagogia da revolução. São Paulo: Expressão Popular, 2002.

MCCLELLAND, James C. Autocrats and Academics: education, culture, and society in Tsarist Russia. Chicago: The University of Chicago Press, 1979.

NABUCO, Joaquim. Um estadista no Império. Rio de Janeiro: Nova Aguilar, 1975.

PEREIRA, Astrojildo. Machado de Assis. Rio de Janeiro: Livraria São José, 1959.

PEVEAR, Richard. Introduction. In: DOSTOEVSKY, Fyodor M. The Brothers Karamázov. London: Vintage, 1992. 
ROMANELLI, Otaíza de Oliveira. História da educação do Brasil (1930/1973). Petrópolis: Vozes, 1978.

SCHWARZ, Roberto. Ao vencedor as batatas: forma literária e processo social nos inícios do romance brasileiro. $5^{\text {a }}$ ed. São Paulo: Duas Cidades, 2000.

, Roberto. Duas meninas. São Paulo: Companhia das Letras, 1997.

, Roberto. Um mestre na periferia do capitalismo: Machado de Assis. São Paulo: Duas Cidades, 1990.

XAVIER, Maria Elisabete Sampaio Prado. A educação da sociedade brasileira: um exame das concepções e das práticas educacionais na produção literária nacional (1840 - 1920). 175 p. Tese (Livre-Docência) - Faculdade de Educação, UNICAMP, Campinas, 2002.

\section{Notas:}

1. Sobre estudos que relacionam Literatura e História, especificamente, neste caso, a obra de Machado de Assis, ver:

PEREIRA, Astrojildo. Machado de Assis. Rio de Janeiro: Livraria São José, 1959.

FAORO, Raymundo. Machado de Assis: a pirâmide e o trapézio. $3^{\text {a }}$ ed. Rio de Janeiro: Globo, 1988.

SCHWARZ, Roberto. Ao vencedor as batatas: forma literária e processo social nos inícios do romance brasileiro. $5^{\text {a }}$ ed. São Paulo: Duas Cidades, 2000.

GLEDSON, John. Machado de Assis - impostura e realismo: uma reinterpretação de Dom Casmurro. Tradução Fernando Py. São Paulo: Companhia das Letras, 1991.

CHALHOUB, Sidney. Machado de Assis: historiador. São Paulo: Companhia das Letras, 2003.

No campo da História da Educação, destacamos este estudo que analisa vários autores literários brasileiros:

XAVIER, Maria Elisabete Sampaio Prado. A educação da sociedade brasileira: um exame das concepções e das práticas educacionais na produção literária nacional (1840 - 1920). Tese (Livre-Docência). Faculdade de Educação - UNICAMP, Campinas, 2002.

2. Considerando que a língua russa utiliza outro alfabeto, a grafia de palavras desta língua em outros idiomas ocorre pelo processo de transliteração, que é a transposição de um sistema escrito para outro. Este processo pode variar de acordo com o idioma para o qual se transpõe uma determinada língua. Ao escrever o nome do autor e da obra analisada neste estudo em português, utilizamos o padrão de transliteração empregado na edição da Obra Completa de Dostoiévski, da Editora Nova Aguilar, que apresenta a forma Karamázovi, para o título do romance e para se referir aos irmãos de modo coletivo, sendo utilizada a forma Karamázov, quando um dos personagens é mencionado individualmente, por exemplo, Ivan Karamázov. Para a menção do nome do autor e da obra no abstract utilizamos a translisteração utilizada na edição em inglês deste romance da Editora Vintage, de Londres - The Brothes Karamazov.

3. Além da proximidade temporal da publicação dos romances Os Irmãos Karamázovi, 1880, e Memórias Póstumas de Brás Cubas, 1881, gostaríamos de mencionar também as datas de nascimento e de morte de ambos os escritores, para maior esclarecimento do leitor. Fiódor Mikháilovitch Dostoiévski nasceu em 1821 e faleceu em 1881, e Joaquim Maria Machado de Assis nasceu em 1839 e faleceu em 1908.

Recebido em: $\quad 19 / 04 / 11$

Aprovado em: $16 / 10 / 11$ 